\title{
PENGEMBANGAN BAHAN AJAR MATA PELAJARAN DASAR DAN PENGUKURAN LISTRIK UNTUK SEKOLAH MENENGAH KEJURUAN
}

\author{
Aliangga Kusumam, Mukhidin, Bachtiar Hasan \\ Pendidikan Teknologi dan Kejuruan, Sekolah Pascasarjana, Universitas Pendidikan Indonesia \\ Email:mukhidin@upi.edu
}

\begin{abstract}
This study is aimed to develop teaching materials of basic electrical and electrical measurement, and to find out the feasibility of the teaching materials that have been developed in SMK Negeri 1 Koba Bangka. This study used the method of Research and Development $(R \& D)$ that begins with the preliminary study followed by the development phase and the product assessment. The subjects that consisted of three experts and 28 students of the Department of Electrical Installation Engineering were determined using purposive sampling technique. The data collection technique used documentation, interviews and questionnaires. The procedure of this study is the process of preparing the teaching materials through the following stages: (a) A preliminary study, by conducting interviews with the head of the program and the teachers. The analysis of the syllabus and core competencies. (b) Collecting learning resources and literature as well as the main points of the materials. (c) Preparing the draft of the materials. (d) The limited trial of the products (e) The extensive product testing. (f) The data analysis and evaluation. The results were the development of the teaching materials was based on the curriculum of 2013 and the syllabus of basic electrical and electrical measurement. The teaching materials were developed starting from the materials of electric current and electron current, electrical materials, passive elements, active elements, direct current resistive circuits, two poles theorem, power and efforts, switching circuits, the system of units of measurement, measuring instruments and electrical measurements, and the types of measuring devices.
\end{abstract}

Keywords: electrical measurements, teaching materials development

\begin{abstract}
ABSTRAK
Penelitian ini bertujuan untuk mengembangkan bahan ajar dasar dan pengukuran listrik, dan mengetahui kelayakan bahan ajar yang telah dikembangkan menurut expert judgment dan peserta didik di SMKN I Koba Bangka. Metode penelitian ini menggunakan Research and Development ( R \& D) yang diawali dengan studi pendahuluan dilanjutkan tahap pengembangan dan penilaian produk. Subjek penelitian ditentukan dengan menggunakan teknik purposive sampling yang terdiri dari tiga orang expert judgement dan 28 orang peserta didik teknik instalasi pemanfaatan tenaga listrik. Pengumpulan data dengan teknik studi dokumentasi, wawancara dan kuesioner berupa angket. Prosedur penelitian ini adalah proses penyusunan bahan ajar dasar dan pengukuran listrik melalui tahap-tahap sebagai berikut: (a) Studi pendahuluan, dengan melakukan wawancara terhadap ketua program dan guru. Studi analisis silabus dan menganalisa kompetensi dasar dalam penyusunan bahan ajar (b) Mengumpulkan sumber belajar dan literatur serta pokok-pokok materi yang akan disusun. (c) Penyusunan draft bahan ajar dasar dan pengukuran listrik. (d) Uji coba terbatas produk. (e) Uji coba lebih luas produk. (f) Pengolahan data dan evaluasi. Kesimpulan penelitian ini adalah pengembangan bahan ajar mata pelajaran dasar dan pengukuran listrik yaitu bahan dikembangkan dari kurikulum 2013 dan silabus mata pelajaran dasar dan pengukuran listrik. Materi bahan ajar dikembangkan mulai dari materi arus listrik dan arus elektron, bahanbahan listrik, elemen pasif, elemen aktif, rangkaian resistif arus searah, teorema dua kutub, daya dan usaha, peralihan rangkaian, sistem satuan pengukuran, alat ukur dan pengukuran listrik, dan jenis alat ukur.
\end{abstract}

Kata Kunci: pengembangan bahan ajar, pengukuran listrik

\section{PENDAHULUAN}

Mutu pendidikan merupakan konsekuensi langsung dari satu perubahan dan perkembangan berbagai aspek kehidupan. Tuntutan terhadap mutu pendidikan tersebut menjadi syarat terpenting untuk dapat menjawab tantangan perubahan dan perkembangan itu. Hal itu 
diperlukan untuk mendukung terwujudnya manusia Indonesia yang cerdas dan berkehidupan yang damai, terbuka, dan berdemokrasi, serta mampu bersaing secara terbuka di era global. Untuk itu, pembenahan dan penyempurnaan kinerja pendidikan menjadi hal yang pokok. Pendidikan di Indonesia diarahkan untuk membentuk peserta didik agar menjadi warga negara Indonesia guna mencapai bangsa Indonesia yang bermartabat.

Kurikulum merupakan alat pendidikan. Fungsi kurikulum adalah menentukan lulusan agar dapat menentukan perubahan perilaku setelah siswa tersebut mengikuti proses belajar mengajar. Kurikulum berkembang di Indonesia sejak jaman kemerdekan hingga sekarang ini yang berlaku kurikulum 2006 dan 2013. Antara keduanya ada perbedaan terutama dalam jumlah materi dan sistem penilaian. Implementasi kurikulum diterapkan dengan baik tergantung dari guru dan peserta didik. Kesiapan dan kemampuan peserta didik sebagai subyek sekaligus penerima layanan pendidikan dalam menyerap pendidikan yang bermutu juga bergantung pada guru sebagai fasilitor belajar. Guru memegang peran sentral terhadap proses dan hasil pedidikan karena guru merupakan subyek yang diharapkan mampu menterjemahkan kurikulum menjadi lebih operasional dalam bentuk silabus maupun bahan ajar. Peran guru di masing-masing sekolah memiliki kewenangan dan tanggung jawab untuk merumuskan kompetensi lulusannya serta menyusun bahan ajar bagi peserta didik.

Perubahan kurikulum 2013 berorientasi pada penguatan proses pembelajaran yang memicu peserta didik mampu berpikir kritis dan memiliki kemampuan seimbang pada aspek sikap, pengetahuan dan keterampilan. Hal tersebut menuntut kreativitas guru dalam menjalankan atau melaksanakan proses belajar mengajar. Guru diharapkan mampu untuk merancang ataupun menyusun bahan ajar yang berperan dalam menentukan keberhasilan proses belajar dan pembelajaran melalui sebuah bahan ajar. Widodo dan Jasmadi (2008: 40) menyatakan bahwa bahan ajar adalah seperangkat sarana atau alat pembelajaran yang berisikan materi pembelajaran, metode, dalam rangka mencapai tujuan yang diharapkan, yaitu mencapai kompetensi atau subkompetensi dengan segala kompleksitas. Pengembangan bahan pembelajaran atau bahan ajar disusun untuk menjadi salah satu referensi yang akan mendukung perkembangan peserta didik agar ada keseimbangan antara kebutuhan jasmani dan rohani. Alat bantu belajar termasuk salah satu unsur dinamis dalam belajar. Kedudukan alat bantu memiliki peranan yang penting karena dapat membantu proses belajar siswa.

Hamalik dalam Harjanto (2008: 220) mengatakan bahwa di dalam pengembangan bahan ajar berbagai aspek-aspek yang dapat jadi patokan, antara lain: (1) Konsep adalah suatu ide atau gagasan. (2) Prinsip adalah suatu kebenaran dasar sebagai titik tolak untuk berpikir atau merupakan suatu petunjuk untuk berbuat atau melaksanakan suatu. (3) Fakta adalah sesuatu yang telah terjadi atau yang telah dikerjakan atau dialami. (4) Proses adalah serangkaian dari perubahan, gerakan-gerakan perkembangan. (5) Nilai adalah suatu pola, ukuran atau merupakan suatu tipe atau model. (6) Keterampilan adalah kemampuan berbuat sesuatu yang baik. Manfaat tersebut dibedakan menjadi dua macam, yaitu manfaat bagi guru dan siswa (Prastowo, 2012: 301). Manfaat yang diperoleh oleh guru yaitu bahan ajar sesuai dengan tuntutan kurikulum, tidak tergantung dengan buku teks dan buku paket bantuan pemerintah, sedangkan manfaat yang diperoleh peserta didik yaitu, menciptakan pembelajaran menarik, menumbuhkan motivasi, mengurangi ketergantungan dan mendapatkan kemudahan dalam mempelajari setiap indikator yang terdapat pada perangkat pembelajaran yang disusun oleh guru.

\section{METODE}

Penelitian ini menggunakan metode penelitian dan pengembangan (Research and Development) yang diawali dengan studi pendahuluan dan sampai tahap uji produk 
dengan batasan uji produk terbatas. Penelitian pengembangan berdasarkan Sugiono (2012: 497) adalah metode penelitian yang digunakan untuk menghasilkan produk tertentu dan menguji keefektifan produk tersebut. Penelitian pengembangan bukan merupakan penelitian yang dimaksudkan untuk menghasilkan teori melainkan untuk menghasilkan produk tertentu.

Metode penelitian dan pengembangan dilaksanakan melalui beberapa langkah. Ada beberapa metode digunakan dalam pelaksanaan penelitian dan pengembangan, yaitu: deskriptif, evaluatif, dan eksperimental. Metode evaluatif digunakan untuk mengevaluasi proses uji coba pengembangan suatu produk. Penelitian dan pengembangan pada dasarnya memiliki dua tujuan utama, yaitu mengembangkan produk dan menguji keefektifan produk dalam mencapai tujuan. Langkah-langkah penelitian pada metode riset dan pengembangan digunakan dalam penelitian ini karena penelitian ini menggunakan pengembangan suatu produk. Langkah-langkah pengembangan instrumen adalah sebagai berikut: studi pendahuluan yang meliputi studi literatur, studi lapangan, wawancara, pengumpulan materi, penyususnan draft produk awal, uji coba produk atau uji terbatas, revisi dan perbaikan produk, ujicoba lebih luas atau revisi produk.

Studi pendahuluan merupakan tahap pertama. Kegiatan yang dilakukan adalah studi lapangan yang dilakukan di SMK Negeri 1 Koba Kabupaten Bangka Tengah Propinsi Bangka Belitung. Pada studi awal, data-data awal dan informasi dikumpulkan. Hasil studi pendahuluan ini digunakan sebagai identifikasi kebutuhan untuk mengembangkan bahan ajar dasar dan pengukuran listrik untuk Sekolah Menengah Kejuruan. Studi dokumentasi, yaitu pencarian kurikulum, silabus mengenai mata pelajaran dasar dan pengukuran listrik. Analisis kompetensi inti dan kompetensi dasar pada mata pelajaran dasar dan pengukuran listrik. Peneliti kemudian menentukan kompetensi dasar dan urutan materi yang dibutuhkan dalam pengembangan bahan ajar dasar dan pengukuran listrik untuk Sekolah Menengah
Kejuruan. Tahap pengembangan terdiri dari kegiatan mengumpulkan sumber-sumber bahan ajar atau literatur, menentukan materi pokok yang akan dibahas berdasarkan silabus, membuat kerangka materi yang dijadikan bahan, penentuan urutan pembelajaran, menyiapkan materi pembelajaran, penyusunan dan desain draft bahan ajar, melakukan uji coba terhadap produk kepada expert judgement, melakukan revisi produk, melakukan uji coba terbatas dan uji coba lebih luas kepada peserta didik.

Tahap evaluasi merupakan tahap analisa pengolahan data yang sudah didapatkan untuk mengetahui kelayakan bahan ajar dasar dan pengukuran listrik. Penyempurnaan produk dan penarikan kesimpulan. Uji coba produk meliputi evaluasi tahap pertama yang merupakan tinjauan guru dan ahli, bertujuan untuk menggali komentar dan saran, baik secara tertulis maupun lisan, dangan cara melakukan diskusi dan menyerahkan rancangan buku ajar untuk tinjau atau review dengan acuan instrumen evaluasi isi, bahasa, dan kegrafikan. Pengujian dilakukan oleh beberapa orang guru dan ahli di bidang studi dasar dan pengukuran listrik. Proses uji oleh guru dan ahli untuk menilai materi yang disajikan sudah sesuai dengan silabus dan dapat digunakan dalam pembelajaran dasar dan pengukuran listrik, serta untuk menilai aspek kelayakan isi, bahasa dan kegrafikan, yaitu: (a) review pada evaluasi isi bertujuan untuk mengevaluasi isi buku ajar, dan isi materi (b) review pada evaluasi bahasa bertujuan untuk mengevaluasi bahasa yang digunakan, keruntutan dan kesesuaian materi buku ajar, dan (c) review pada evaluasi kegrafikan bertujuan untuk mengevaluasi kualitas fisik buku ajar, ukuran buku, desain isi buku.

Evaluasi peserta didik dilakukan dengan uji coba materi pada peserta didik untuk mengetahui komentar dan saran penilaian buku ajar dengan acuan instrumen evaluasi pada aspek tampilan, aspek penyajian materi dan aspek manfaat. Uji coba dilakukan pada pengujian terbatas dan lebih luas terhadap peserta didik. Penilaian pertama dilakukan oleh kelompok terbatas peserta didik. Hasil data dari 
peserta didik dianalisis untuk digunakan sebagai pijakan merevisi buku ajar. Penelitian ini dilakukan di Sekolah Menengah Kejuruan Negeri 1 Koba, Bangka Tengah. Teknik pengambilan subjek penelitian menggunakan metode purposive sampling. Subjek penelitian adalah peserta didik kelas X Sekolah Menengah Kejuruan Negeri 1 Koba. Adapun pertimbangan pengambilan sampel karena peserta didik kelas $\mathrm{X}$ sedang mengikuti pembelajaran mata pelajaran dasar dan pengukuran listrik.

Instrumen yang digunakan pada penelitian pengembangan ini sesuai dengan tahap penelitian. Tujuan penelitian ini adalah mengembangkan dan mewujudkan bahan ajar dasar dan pengukuran listrik yang layak untuk pembelajaran. Instrumen penelitian yang digunakan terdiri dari studi dokumentasi, pedoman wawancara, instrumen angket expert judgement dan peserta didik tentang buku ajar dasar dan pengukuran listrik yang digunakan. Teknik pengumpulan data yang digunakan dalam penelitian ini untuk mendapatkan datadata yang sesuai dengan tujuan penelitian adalah: (a) Studi dokumentasi yang digunakan untuk mengetahui dokumen-dokumen penting yang berhubungan dengan pelaksanaan pembelajaran dasar dan pengukuran listrik. Teknik penelitian kajian dokumentasi guna memperoleh informasi yang berhubungan dengan masalah penelitian. (b) Wawancara yang digunakan untuk mewawancarai guru, expert judgement, dan sumber lain yang terkait di lingkungan SMK. Teknik wawancara yang digunakan dalam penelitian ini adalah wawancara tidak terstruktur. Sesuai dengan bentuk wawancara, maka peneliti tidak terikat secara ketat pada pedoman wawancara. (c) Angket yang digunakan untuk mengukur efektivitas produk. Instrumen kuisioner disusun dengan tujuan untuk mengevaluasi kualitas bahan ajar sehingga produk tersebut layak untuk digunakan. Data yang diperoleh dari serangkaian uji coba berupa data penilaian, tanggapan, saran-saran yang diperoleh dari uji coba lapangan, dan dari guru mata pelajaran dasar dan pengukuran listrik.
Data-data tersebut digunakan untuk merevisi produk yang akan dikembangkan. Angket penilaian bahan ajar untuk ahli terdiri dari beberapa komponen, yaitu kelayakan isi, kelayakan bahasa dan kelayakan kegrafikan. Indikator-indikator kualitas pengembangan bahan ajar dari aspek isi bahan ajar terdiri dari relevansi materi, bobot materi dan tata bahasa, dan desain bahan ajar terdiri dari tata letak dan tulisan atau bahasa, kelengkapan penyajian, kelengkapan unsur tata letak, perpaduan warna serta ilustrasi dan gambar. Angket penilaian responden, disusun dengan menggunakan kriteria penilaian skala likert. Pada skala likert, awalnya skor tertinggi tiap butir 5 dan rendah 1 . Ketika pengukuran sering terjadi kecenderungan responden memilih dalam kategori 3, untuk menghindari hal itu skala likert dimodifikasi dengan hanya menggunakan pilihan 4 pilihan yaitu 4 (Sangat baik); 3 (Baik); 2 (Cukup); 1 (Kurang) (Direktorat Pembinaan SMK 2008: 13). Teknik analisis data dalam penelitian ini menggunakan analisis deskriptif persentase melalui pemaparan data atau simpulan data yang diolah menggunakan teknik presentase yang dibagi menjadi lima kategori dengan rumus sebagai berikut:

$$
\mathrm{P}=\frac{\sum \mathrm{x} 100 \%}{\mathrm{n}}
$$

Keterangan: $\mathrm{P}=$ Persentase nilai yang dicapai

$\Sigma=$ Jumlah

$\mathrm{n}=$ Jumlah seluruh responden

Sebagai ketentuan dalam memberikan makna dan pengambilan keputusan, maka digunakan ketetapan dalam Tabel 1 sebagai berikut.

Tabel 1. Kriteria Tingkat Ketercapaian

\begin{tabular}{cll}
\hline $\begin{array}{c}\text { Tingkat Pencapaian } \\
\text { Kualifikasi }\end{array}$ & & Keterangan \\
\hline $90 \%-100 \%$ & Sangat baik & Tidak perlu direvisi \\
$75 \%-89 \%$ & Baik & Tidak perlu direvisi \\
$65 \%-74 \%$ & Cukup & Direvisi \\
$55 \%-64 \%$ & Kurang & Direvisi \\
$0-54 \%$ & Kurang & Direvisi \\
\hline
\end{tabular}


Produk dinyatakan baik, layak, dan menarik apabila hasil observasi berada pada kualifikasi minimal baik. Sehingga produk atau bahan ajar mata pelajaran dasar dan pengukuran listrik tidak perlu direvisi lagi.

\section{HASIL DAN PEMBAHASAN}

Sebagai pengembangan tahap awal bahan ajar berupa buku teks ini harus melalui tahap uji ahli untuk menilai kelayakan bahan ajar ini. Penilaian komponen bahan ajar melibatkan ahli dari jurusan listrik terdiri dari tiga orang guru yang memiliki pengalaman dalam pembelajaran dan materi mata pelajaran dasar dan pengukuran listrik. Dalam hal ini guru menilai dengan mengisi angket yang diberikan. Penilaian ini meliputi aspek kelayakan isi, kelayakan bahasa, dan kelayakan kegrafikan. Proses uji kelayakan dilakukan untuk mengetahui apakah materi yang disajikan pada bahan ajar sudah sesuai dengan silabus, bahasa yang digunakan sudah sesuai dan kegrafikan sudah sesuai dengan materi pelajaran. Berikut ini merupakan data hasil penilaian expert jugment pada bahan ajar dasar dan pengukuran listrik secara rinci dijelaskan dalam Tabel 2, Tabel 3 dan Tabel 4.

\begin{tabular}{|c|c|c|c|c|c|}
\hline \multirow{3}{*}{$\begin{array}{l}\text { Sub Komponen } \\
\text { 1. Kelayakan Isi } \\
\text { A. Kesesuaian uraian materi dengan } \\
\text { KI dan KD }\end{array}$} & \multirow{2}{*}{ Butir Penilaian } & \multicolumn{2}{|c|}{ Expert Judgement } & \multirow[t]{2}{*}{$\%$} & \multirow[t]{2}{*}{ Ket } \\
\hline & & & & & \\
\hline & 1. Keluasan materi & $\begin{array}{l}\text { Expert } 1 \\
\text { Expert } 2 \\
\text { Expert } 3\end{array}$ & $\begin{array}{l}3 \\
4 \\
4\end{array}$ & \multicolumn{2}{|c|}{$91.67 \%$ Sangat Baik } \\
\hline & 2. Kedalaman materi & Expert 1 & 3 & \multirow{3}{*}{$75.00 \%$} & \multirow{3}{*}{ Baik } \\
\hline & & Expert 2 & 3 & & \\
\hline & & Expert 3 & 3 & & \\
\hline & 3. Pilihan Tema & $\begin{array}{l}\text { Expert } 1 \\
\text { Expert } 2\end{array}$ & $\begin{array}{l}3 \\
3\end{array}$ & \multirow{2}{*}{$75.00 \%$} & \multirow{2}{*}{ Baik } \\
\hline & & Expert 3 & 3 & & \\
\hline \multirow[t]{6}{*}{ B. Keakuratan materi } & 4. Keakuratan fakta dan konsep & Expert 1 & 3 & \multirow{3}{*}{$75.00 \%$} & \multirow{3}{*}{ Baik } \\
\hline & & Expert 2 & 3 & & \\
\hline & & Expert 3 & 3 & & \\
\hline & 5. Keakuratan ilustrasi & Expert 1 & 4 & \multirow{3}{*}{$75.00 \%$} & \multirow{3}{*}{ Baik } \\
\hline & & Expert 2 & 3 & & \\
\hline & & Expert 3 & 2 & & \\
\hline \multirow{5}{*}{ C. Materi pendukung pembelajaran } & 6. Kesesuaian dengan perkembangan & Expert 1 & 4 & & \\
\hline & ilmu & $\begin{array}{l}\text { Expert } 2 \\
\text { Expert } 3\end{array}$ & $\begin{array}{l}4 \\
3\end{array}$ & $91.67 \%$ & Sangat Baik \\
\hline & 7. Kontekstual & Expert 1 & 3 & & \\
\hline & & Expert 2 & 4 & $75.00 \%$ & Baik \\
\hline & & Expert 3 & 2 & & \\
\hline 2. Kelayakan Penyajian & & & & & \\
\hline D. Teknik Penyajian & 8. Keruntutan konsep & Expert 1 & 3 & & \\
\hline & & Expert 2 & 3 & $66.67 \%$ & Cukup \\
\hline & & Expert 3 & 2 & & \\
\hline & 9. Kekonsistenan sistematika & Expert 1 & 2 & & \\
\hline & & Expert 2 & 4 & $66.67 \%$ & Cukup \\
\hline & & Expert 3 & 2 & & \\
\hline & 10. Keseimbangan antar bab & Expert 1 & 3 & & \\
\hline & & Expert 2 & 3 & $66.67 \%$ & Cukup \\
\hline & & Expert 3 & 2 & & \\
\hline E. Penyajian Pembelajaran & 11. Berpusat pada peserta didik & Expert 1 & 3 & & \\
\hline & & Expert 2 & 3 & $66.67 \%$ & Cukup \\
\hline & & Expert 3 & 2 & & \\
\hline & 12. Keakuratan ilustrasi & Expert 1 & 3 & & \\
\hline & & Expert 2 & 3 & $75.00 \%$ & Baik \\
\hline & & Expert 3 & 3 & & \\
\hline & 13. Memperhatikan aspek keselamatan & Expert 1 & 3 & & \\
\hline & kerja & Expert 2 & 3 & $66.67 \%$ & Cukup \\
\hline & & Expert 3 & 2 & & \\
\hline & 14. Variasi penyajian & Expert 1 & 2 & & \\
\hline & & Expert 2 & 3 & $66.67 \%$ & Cukup \\
\hline F. Kelengkapan Penyajian & 15. Kata Pengantar & $\begin{array}{l}\text { Expert } 3 \\
\text { Expert } 1\end{array}$ & $\begin{array}{l}3 \\
3\end{array}$ & & \\
\hline & & Expert 2 & 4 & $83.33 \%$ & Baik \\
\hline & & Expert 3 & 3 & & \\
\hline & 16. Daftar isi & Expert 1 & 4 & & \\
\hline & & Expert 2 & 4 & $91.67 \%$ & Sangat Baik \\
\hline & & Expert 3 & 3 & & \\
\hline & 17. Daftar pustaka & Expert 1 & 4 & & \\
\hline & & Expert 2 & 4 & $91.67 \%$ & bangat Baik \\
\hline & & Expert 3 & 3 & & \\
\hline & 18. Evaluasi & Expert 1 & 3 & & \\
\hline & & Expert 2 & 4 & $75.00 \%$ & Baik \\
\hline & & Expert 3 & 2 & & \\
\hline & 19. Proporsi gambar dan teks yang tepat & Expert 1 & 2 & & \\
\hline & & Expert 2 & 4 & $66.67 \%$ & Cukup \\
\hline & & Expert 3 & 2 & & \\
\hline & 20. Ilustrasi yang mendukung pesan & Expert 1 & 2 & & \\
\hline & & Expert 2 & 3 & $66.67 \%$ & Cukup \\
\hline & & Expert 3 & 3 & & \\
\hline Jumlah & & & 18 & & \\
\hline Persentase & & & & $75.42 \%$ & Baik \\
\hline
\end{tabular}


Tabel 3. Penilaian Buku Teks Kelayakan Bahasa

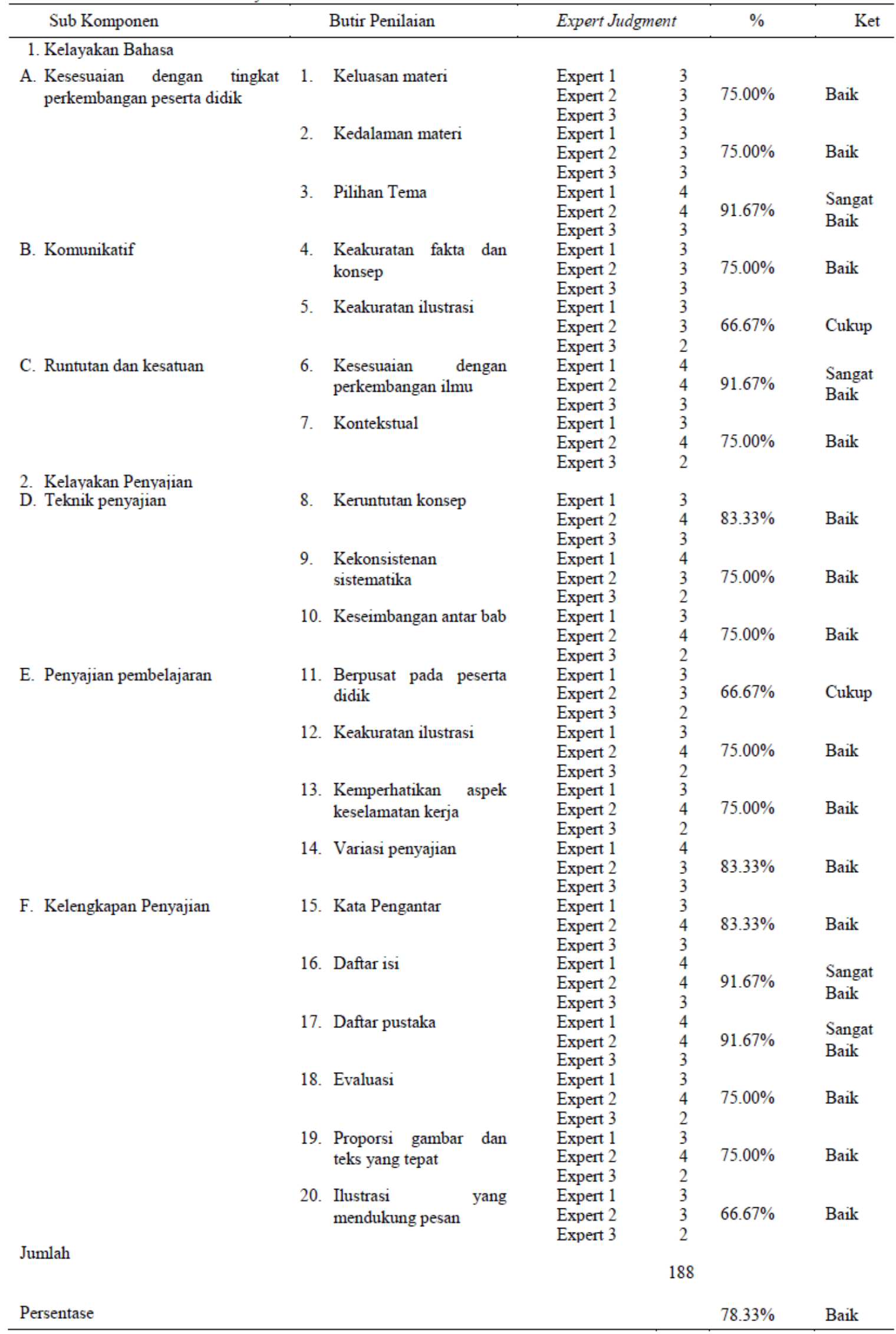




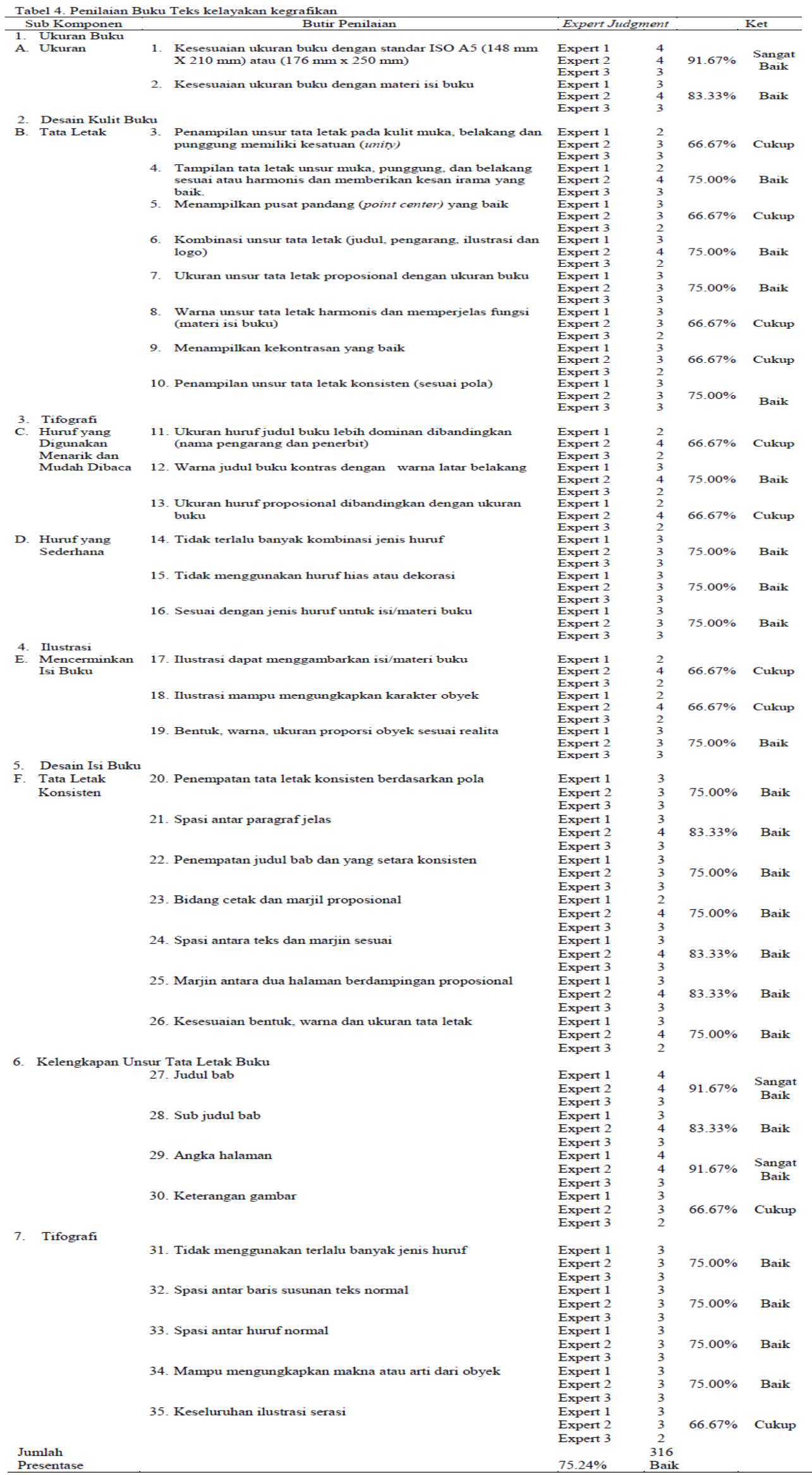


Tabel 2 menjelaskan bahwa dalam aspek kelayakan isi terdapat dua indikator yang dinilai. Indikator pertama adalah kelayakan isi yang mencakup kategori kesesuaian uraian materi dengan KI dan KD, keakuratan materi, dan materi pendukung pembelajaran. Indikator kedua adalah kelayakan penyajian yang mencakup kategori teknik penyajian, penyajian pembelajaran, dan kelengkapan penyajian. Nilai persentase rata-rata yang diperoleh dalam kategori aspek kelayakan isi adalah 75,42\% yang termasuk dalam kategori sangat baik. Bahan ajar sudah cukup memberi penjelasan dan gambaran materi pembelajaran pada peserta didik. Saran yang diberikan oleh expert judgment adalah pada awal buku lebih baik dilengkapi dengan kompetensi inti dan kompetensi dasar, pembelajaran pada pokok bahasan tertentu perlu tambahan materi, kekinian ilmu perlu ditingkatkan dan pada bab peralihan rangkaian ditambahkan contoh latihan serta perhitungannya.

Tabel 3 menjelaskan bahwa dalam aspek kelayakan bahasa terdapat dua indikator yang dinilai. Indikator pertama adalah kelayakan bahasa yang mencakup kategori kesesuaian dengan tingkat perkembangan peserta didik dan komunikatif. Indikator kedua adalah kelayakan penyajian yang mencakup kategori teknik penyajian, penyajian pembelajaran, kelengkapan penyajian. Nilai persentase rata-rata yang diperoleh dalam kategori aspek kelayakan bahasa adalah $78,33 \%$ yang termasuk dalam kategori sangat baik. Saran yang diberikan oleh expert judgement adalah penyajian bahasa disesuaikan dengan kemampuan peserta didik kelas $\mathrm{X}$ dan dengan bahasa yang sederhana dan lugas.

Tabel 4 memaparkan dalam aspek kelayakan kegrafikan terdapat tiga indikator yang dinilai. Indikator pertama adalah ukuran buku yang mencakup kategori ukuran. Indikator kedua adalah desain kulit buku yang mencakup kategori tata letak, tifografi dan ilustrasi. Indikator ketiga adalah desain isi buku yang mencakup kategori tata letak tifografi. Nilai persentase ratarata yang diperoleh dalam kategori aspek kelayakan kegrafikan adalah $75,24 \%$ yang termasuk dalam kategori sangat baik. Saran yang diberikan oleh expert judgement adalah tampilan dan tata letak gambar diharapkan proporsional dengan ukuran buku serta sudut pandang gambar harus menarik.

Sebagai pengembangan tahap awal bahan ajar berupa buku teks ini harus melalui uji coba terbatas untuk menilai kelayakan buku ini. Uji coba terbatas ini dilaksanakan oleh peserta didik. Dalam hal ini peserta didik memberikan penilaian dengan mengisi angket yang diberikan. Penilaian tersebut meliputi aspek tampilan, penyajian materi dan manfaat. Hasil penilaian dijadikan sebagai salah satu masukan untuk merevisi bahan ajar.

Tabel 5 berikut ini menguraikan data hasil penilaian peserta didik mata pelajaran dasar dan pengukuran listrik. Data tersebut menjelaskan bahwa terdapat 30 poin penilaian yang mencakup aspek kelayakan isi, aspek penyajian materi, dan aspek manfaat yang diujikan terhadap bahan ajar dasar dan pengukuran listrik yang peneliti kembangkan. Persentase rata-rata total dari ke 30 poin tersebut adalah sebesar $77.05 \%$ yang termasuk dalam kategori baik, yang artinya tidak memerlukan adanya revisi kembali. Beberapa saran yang diberikan siswa antara lain mengenai beberapa gambar atau ilustrasi yang tidak terlalu jelas, tampilan bahasa yang jelas dan mudah dimengerti, peserta didik agar dapat belajar dengan terarah dan lebih rajin, dan terdapat beberapa ejaan yang salah tulis. 


\begin{tabular}{|c|c|c|c|c|c|}
\hline No & $\begin{array}{r}\text { Pertanyaan } \\
\end{array}$ & Pilihan Jawaban & Jumlah Siswa & $\%$ & Ket \\
\hline 1 & Tampilan buku ini menarik & Sangat Baik & 2 & & \\
\hline & & Baik & 10 & $76.92 \%$ & Baik \\
\hline & & $\begin{array}{l}\text { Cukne } \\
\text { Kurang }\end{array}$ & $\begin{array}{l}1 \\
0\end{array}$ & & \\
\hline 2 & Terdapat keserasian ukuran, warna dan & Sangat Baik & 6 & & \\
\hline & tata letak dalam sampul buku ini & $\begin{array}{l}\text { Baik } \\
\text { Cukup }\end{array}$ & $\begin{array}{l}6 \\
1\end{array}$ & $84.62 \%$ & Baik \\
\hline & & Kurang & 0 & & \\
\hline 3 & Kerangka isi pada bagian awal bab & Sangat Baik & 2 & & \\
\hline & membantu memahami isi bacaan & $\begin{array}{l}\text { Baik } \\
\text { Cuknpp }\end{array}$ & 9 & $75.00 \%$ & Baik \\
\hline & & Kurang & 0 & & \\
\hline 4 & Memiliki kejelasan petunjuk pada tiap & Sangat Baik & 3 & & \\
\hline & awal bab. & $\begin{array}{l}\text { Baik } \\
\text { Cukup }\end{array}$ & $\begin{array}{c}10 \\
0\end{array}$ & $80.77 \%$ & Baik \\
\hline & & Kurang & 0 & & \\
\hline 5 & Ukuran dan jenis huruf yang digunakan & Sangat Baik & 6 & & \\
\hline & dalam buku teks ini mudah dibaca & $\begin{array}{l}\text { Baik } \\
\text { Culkup }\end{array}$ & ${ }_{0}^{6}$ & $82.69 \%$ & Baik \\
\hline & & $\begin{array}{l}\text { Cukup } \\
\text { Kurang }\end{array}$ & 1 & & \\
\hline 6 & Kalimat dan paragraf yang digunakan & Sangat Baik & 0 & & \\
\hline & $\begin{array}{l}\text { dalam buku ini jelas dan mudah } \\
\text { dipahami }\end{array}$ & $\begin{array}{l}\text { Baik } \\
\text { Cukup }\end{array}$ & $\begin{array}{c}13 \\
0\end{array}$ & $75.00 \%$ & Baik \\
\hline 7 & & Kurang & 0 & & \\
\hline 要 & $\begin{array}{l}\text { Bahasa yang digunakan sederhana dan } \\
\text { mudah dimengerti }\end{array}$ & $\begin{array}{l}\text { Sangat Baik } \\
\text { Baik }\end{array}$ & $\begin{array}{l}2 \\
6\end{array}$ & & \\
\hline & & Cukup & 5 & $69.23 \%$ & Cukup \\
\hline 8 & Gambar yang disajikan jelas & $\begin{array}{l}\text { Kurang } \\
\text { Sangat Baik }\end{array}$ & $\begin{array}{l}0 \\
6\end{array}$ & & \\
\hline & & Baik & 6 & $82.69 \%$ & Baik \\
\hline & & Kurang & 1 & & \\
\hline 9 & Gambar yang disajikan sudah sesuai & Sangat Baik & 3 & & \\
\hline & $\begin{array}{l}\text { (tidak terlalu banyak dan tidak terlalu } \\
\text { sedikit) }\end{array}$ & $\begin{array}{l}\text { Baik } \\
\text { Cuknup }\end{array}$ & $\begin{array}{l}8 \\
1\end{array}$ & $75.00 \%$ & Baik \\
\hline & & Kurang & 1 & & \\
\hline 10 & Adanya keterangan pada setiap gambar & Sangat Baik & 5 & & \\
\hline & yang disajikan pada buku ini & Baik & 4 & $76.92 \%$ & Baik \\
\hline & & $\begin{array}{l}\text { Cukup } \\
\text { Kurang }\end{array}$ & $\begin{array}{l}4 \\
0\end{array}$ & & \\
\hline 11 & Gambar yang disajikan menarik & Sangat Baik & 5 & & \\
\hline & & Baik & 4 & $76.92 \%$ & Baik \\
\hline & & $\begin{array}{l}\text { Cukup } \\
\text { Kurang }\end{array}$ & $\begin{array}{l}4 \\
0\end{array}$ & & \\
\hline 12 & Gambar yang disajikan sesuai materi & Sangat Baik & 6 & & \\
\hline & - & $\begin{array}{l}\text { Baik } \\
\text { Cukap }\end{array}$ & 6 & $84.62 \%$ & Baik \\
\hline & & Kurang & 0 & & \\
\hline 13 & - Uraian materi dalam buku ini dapat & Sangat Baik & 5 & & \\
\hline & dipahami dengan mudah & $\begin{array}{l}\text { Baik } \\
\text { Cukupp }\end{array}$ & ${ }_{1}^{7}$ & $82.69 \%$ & Baik \\
\hline & & Kurang & 0 & & \\
\hline 14 & Materi yang disajikan dalam buku ini & Sangat Baik & 1 & & \\
\hline & sudah runtut & $\begin{array}{l}\text { Baik } \\
\text { Cukup }\end{array}$ & $\begin{array}{l}9 \\
3\end{array}$ & $71.15 \%$ & Cukup \\
\hline & & Kurang & 0 & & \\
\hline 15 & Saya dapat mengikuti kegiatan belajar & Sangat Baik & 1 & & \\
\hline & tahap demi tahap dengan mudah & Baik & 8 & & \\
\hline & & $\begin{array}{l}\text { Cukup } \\
\text { Kurang }\end{array}$ & 4 & $69.23 \%$ & Cukup \\
\hline & & & 0 & & \\
\hline 16 & Saya dapat dengan mudah memahami & Sangat Baik & 2 & & \\
\hline & kalimat yang digunakan dalam buku ini & Baik & 10 & $76.92 \%$ & Baik \\
\hline & & $\begin{array}{l}\text { Cukup } \\
\text { Kurang }\end{array}$ & $\begin{array}{l}1 \\
0\end{array}$ & ro. & \\
\hline & Tidak ada kalimat yang menimbulkan & Sangat Baik & 2 & & \\
\hline & makna ganda dalam buku ini & $\begin{array}{l}\text { Baik } \\
\text { Cukup }\end{array}$ & 10 & $76.92 \%$ & Baik \\
\hline & & Kurang & o & & \\
\hline 18 & Saya dapat memahami lambang atau & Sangat Baik & 6 & & \\
\hline & simbol yang digunakan pada buku ini & $\begin{array}{l}\text { Baik } \\
\text { Culkup }\end{array}$ & $\begin{array}{l}6 \\
1\end{array}$ & $84.62 \%$ & Baik \\
\hline & & Kurang & 0 & & \\
\hline 19 & Saya dapat memahami istilah-istilah & Sangat Baik & 1 & & \\
\hline & dalam buka ini. & Baik & 9 & $71.15 \%$ & Cukup \\
\hline & & $\begin{array}{l}\text { Cukup } \\
\text { Kurang }\end{array}$ & 0 & & \\
\hline 20 & Materi dalam buku ini mendorong & Sangat Baik & 0 & & \\
\hline & keingintahuan saya & $\begin{array}{l}\text { Baik } \\
\text { Cukup }\end{array}$ & $\begin{array}{c}13 \\
0\end{array}$ & $75.00 \%$ & Baik \\
\hline & & Kurang & 0 & & \\
\hline 21 & Penyajian materi dalam buku ini & Sangat Baik & 2 & & \\
\hline & $\begin{array}{l}\text { mendorong saya untuk berdiskusi } \\
\text { dengan teman-teman }\end{array}$ & $\begin{array}{l}\text { Baik } \\
\text { Cukup }\end{array}$ & $\begin{array}{c}11 \\
0\end{array}$ & $78.85 \%$ & Baik \\
\hline & & Kurang & 0 & & \\
\hline 22 & Buku ini memuat latihan soal yang & Sangat Baik & 8 & & \\
\hline & dapat menguji seberapa jauh & Baik & 5 & $90.38 \%$ & Sangat Baik \\
\hline & pemahaman saya mengenai materi & Cukup & 0 & & \\
\hline & yang telah dibahas & Kurang & 0 & & \\
\hline 23 & Latihan soal yang digunakan dalam & Sangat Baik & 5 & & \\
\hline & & Baik & $\begin{array}{l}8 \\
0\end{array}$ & $84.62 \%$ & Baik \\
\hline & & $\begin{array}{l}\text { Cukup } \\
\text { Kurang }\end{array}$ & 0 & & \\
\hline 24 & Saya dapat memahami materi dalam & $\begin{array}{l}\text { Kurtang } \\
\text { Sangat Baik }\end{array}$ & o & & \\
\hline & buku ini dengan mudah & Baik & 12 & $73.08 \%$ & Cukup \\
\hline & & $\begin{array}{l}\text { Cukup } \\
\text { Kurang }\end{array}$ & $\stackrel{1}{0}_{0}$ & & \\
\hline 25 & Saya merasa lebih mudah belajar & $\begin{array}{l}\text { Kutrang } \\
\text { Sangat Baik }\end{array}$ & 2 & & \\
\hline & dengan menggunakan buku ini & Baik & 6 & $69.23 \%$ & Cukup \\
\hline & & $\begin{array}{l}\text { Cukup } \\
\text { Kurang }\end{array}$ & $\begin{array}{l}5 \\
0\end{array}$ & & \\
\hline 26 & Saya sangat tertarik menggunakan & Sangat Baik & 6 & & \\
\hline & buku ini & Baik & 7 & $86.54 \%$ & Baik \\
\hline & & $\begin{array}{l}\text { Cukup } \\
\text { Kurang }\end{array}$ & $\begin{array}{l}0 \\
0\end{array}$ & & \\
\hline 27 & Buku ini membuat saya senang & Sangat Baik & 3 & & \\
\hline & $\begin{array}{l}\text { mempelajari mata pelajaran pekerjaan } \\
\text { dasar elektromekanik }\end{array}$ & $\begin{array}{l}\text { Baik } \\
\text { Cukupp }\end{array}$ & $\begin{array}{c}10 \\
0\end{array}$ & $80.77 \%$ & Baik \\
\hline & & Kurang & 0 & & \\
\hline 28 & Dengan menggunakan buku ini saya & Sangat Baik & 1 & & \\
\hline & belajar menjadi lebih terarah dan runtut & Bail & 7 & $67.31 \%$ & Cukup \\
\hline & & $\begin{array}{l}\text { Cukup } \\
\text { Kurang }\end{array}$ & 0 & & \\
\hline 29 & Buku ini memiliki kesesuaian gambar & Sangat Setuju & 2 & & \\
\hline & untuk memperjelas materi & Sangat Baik & $\begin{array}{c}11 \\
0\end{array}$ & $78.85 \%$ & Baik \\
\hline & & $\begin{array}{l}\text { Baik } \\
\text { Cukup }\end{array}$ & 0 & & \\
\hline 30 & Saya lebih rajin belajar dengan & Sangat Baik & 0 & & \\
\hline & menggunakan bulku ini & Baik & 8 & $65.38 \%$ & Cukup \\
\hline & & $\begin{array}{l}\text { Culup } \\
\text { Kurang }\end{array}$ & $\begin{array}{l}5 \\
0\end{array}$ & & \\
\hline & Persentase Rata-Rata & & & $77.05 \%$ & Baik \\
\hline
\end{tabular}


Uji coba lebih luas melibatkan 28 orang peserta didik untuk melakukan penilaian kelayakan bahan ajar dasar dan pengukuran listrik. Uji coba dilakukan untuk mengetahui bagaimana penilaian bahan ajar memenuhi aspek kelayakan bahasa, kelayakan isi, kelayakan kegrafikan, aspek penyajian materi dan aspek manfaat. Sebagai pengembangan tahap berikutnya buku teks harus melalui tahap uji coba lebih luas untuk menilai kelayakan buku ini. Uji coba lebih luas dilaksanakan oleh peserta didik SMK Negeri 1 Koba. Dalam hal ini peserta didik memberikan penilaian dengan mengisi angket yang diberikan. Dalam Tabel 6 berikut ini merupakan data hasil penilaian peserta didik mata pelajaran dasar dan pengukuran listrik pada uji coba lebih luas.

\begin{tabular}{|c|c|c|c|c|c|}
\hline$\frac{\text { No }}{1}$ & & $\begin{array}{l}\text { Pilihan Jawaban } \\
\text { SPilab }\end{array}$ & Jum1ah siswa & $\%$ & Ket \\
\hline & Tampilan buku ini menarik & $\begin{array}{l}\text { Sangaat Baik } \\
\text { Baik } \\
\text { Cukup }\end{array}$ & $\begin{array}{l}94 \\
14\end{array}$ & $78.57 \%$ & Baik \\
\hline 2 & $\begin{array}{l}\text { Terdapat keserasian ukuran, warna dan } \\
\text { tata letak dalam sampul buku ini }\end{array}$ & $\begin{array}{l}\text { Kurang } \\
\text { Sangat Baik } \\
\text { Baik } \\
\text { Cukup }\end{array}$ & $\begin{array}{l}0 \\
12 \\
9 \\
7\end{array}$ & $79.46 \%$ & Baik \\
\hline 3 & $\begin{array}{l}\text { Kerangka isi pada bagian awal bab } \\
\text { membantu memahami isi bacaan }\end{array}$ & $\begin{array}{l}\text { Kurang } \\
\text { Sangat Baik } \\
\text { Baik } \\
\text { Cukup }\end{array}$ & $\begin{array}{l}0 \\
\mathrm{~s} \\
19 \\
1\end{array}$ & $81.25 \%$ & Baik \\
\hline 4 & $\begin{array}{l}\text { Memiliki kejelasan petunjuk pada tiap } \\
\text { awal bab }\end{array}$ & $\begin{array}{l}\text { Kurang Baik } \\
\text { Sangat Baik } \\
\text { Baik } \\
\text { Cukup }\end{array}$ & $\begin{array}{l}0 \\
7 \\
21 \\
0\end{array}$ & $81.25 \%$ & Baik \\
\hline 5 & $\begin{array}{l}\text { Ukuran dan jenis huruf yang digunakan } \\
\text { dalam buku teks ini mudah dibaca }\end{array}$ & $\begin{array}{l}\text { Kurang } \\
\text { Sangat Baik } \\
\text { Baik } \\
\text { Cukup }\end{array}$ & $\begin{array}{l}0 \\
12 \\
12\end{array}$ & $83.93 \%$ & Baik \\
\hline 6 & $\begin{array}{l}\text { Kalimat dan paragraf yang digunakan } \\
\text { dalam buku ini jelas dan mudah dipahami }\end{array}$ & $\begin{array}{l}\text { Kurang } \\
\text { Sangat Baik } \\
\text { Baik } \\
\text { Cukup }\end{array}$ & $\begin{array}{l}0 \\
4 \\
24 \\
0\end{array}$ & $78.57 \%$ & Baik \\
\hline 7 & $\begin{array}{l}\text { Bahasa yang digunakan sederhana dan } \\
\text { mudah dimengerti }\end{array}$ & $\begin{array}{l}\text { Kurapg } \\
\text { Kangang Baik } \\
\text { Baik } \\
\text { Cukn Bup } \\
\text { Kukap }\end{array}$ & $\begin{array}{l}0 \\
12 \\
15 \\
1 \\
0\end{array}$ & $84.52 \%$ & Baik \\
\hline $\mathbf{s}$ & Gambar yang disajikan jelas & $\begin{array}{l}\text { Sangat Baik } \\
\text { Baik Buip } \\
\text { Cukup }\end{array}$ & $\begin{array}{l}11 \\
15 \\
2 \\
0\end{array}$ & $83.04 \%$ & Baik \\
\hline 9 & $\begin{array}{l}\text { Gambar yang disajikan sudah sesuai (tidak } \\
\text { terialu banyak dan tidak terialu sedikit) }\end{array}$ & $\begin{array}{l}\text { Sangat Baik } \\
\text { Baik } \\
\text { Cukup } \\
\text { Kurang }\end{array}$ & $\begin{array}{l}11 \\
13 \\
4 \\
0\end{array}$ & $81.25 \%$ & Baik \\
\hline 10 & $\begin{array}{l}\text { Adanya keterangan pada setiap gambar } \\
\text { yang disajikan pada buku ini }\end{array}$ & $\begin{array}{l}\text { Kanang Baik } \\
\text { Baikat Baik } \\
\text { Caikup } \\
\text { Cukup }\end{array}$ & $\begin{array}{c}13 \\
10 \\
1 \\
0\end{array}$ & $89.29 \%$ & Baik \\
\hline 11 & Gambar yang disajikan menarik & $\begin{array}{l}\text { Sangat Baik } \\
\text { Baik } \\
\text { Cukup } \\
\text { Kurang }\end{array}$ & $\begin{array}{l}10 \\
10 \\
2 \\
0\end{array}$ & $82.14 \%$ & Baik \\
\hline 12 & Gambar yang disajikan sesuai materi & $\begin{array}{l}\text { Sangat Baik } \\
\text { Baik } \\
\text { Cukup } \\
\text { Kurang }\end{array}$ & $\begin{array}{l}14 \\
12 \\
2 \\
0\end{array}$ & $85.71 \%$ & Baik \\
\hline 13 & $\begin{array}{l}\text { Uraian materi dalam buku ini dapat } \\
\text { dipahami dengan mudah }\end{array}$ & $\begin{array}{l}\text { Sangat Baik } \\
\text { Baik } \\
\text { Cukup }\end{array}$ & $\begin{array}{c}6 \\
16 \\
6\end{array}$ & $75.00 \%$ & Baik \\
\hline 14 & $\begin{array}{l}\text { Materi yang disajikan dalam buku ini } \\
\text { sudah runtut }\end{array}$ & $\begin{array}{l}\text { Kurang } \\
\text { Sangat Baik } \\
\text { Baik } \\
\text { Cukup }\end{array}$ & $\begin{array}{l}0 \\
5 \\
18 \\
5 \\
0\end{array}$ & $75.00 \%$ & Baik \\
\hline 15 & $\begin{array}{l}\text { Saya dapat mengikuti kegiatan belajar } \\
\text { tahap demi tahap dengan mudah }\end{array}$ & $\begin{array}{l}\text { Kurang } \\
\text { Sangat Baik } \\
\text { Baik } \\
\text { Cukup }\end{array}$ & $\begin{array}{l}9 \\
9 \\
14 \\
5\end{array}$ & $78.57 \%$ & Baik \\
\hline 16 & $\begin{array}{l}\text { Saya dapat dengan mudah memahami } \\
\text { kalimat yang digunakan dalam buku ini }\end{array}$ & $\begin{array}{l}\text { Kurang } \\
\text { Sangat Baik } \\
\text { Baik } \\
\text { Cukup } \\
\text { Kurang }\end{array}$ & $\begin{array}{l}0 \\
5 \\
18 \\
5 \\
0\end{array}$ & $75.00 \%$ & Baik \\
\hline 17 & $\begin{array}{l}\text { Tidak ada kalimat yang menimbulkan } \\
\text { makna ganda dalam buku ini }\end{array}$ & $\begin{array}{l}\text { Kurang } \\
\text { Sangat Baik } \\
\text { Baik } \\
\text { Cukup }\end{array}$ & $\begin{array}{l}0 \\
8 \\
13 \\
7\end{array}$ & $75.89 \%$ & Baik \\
\hline 18 & $\begin{array}{l}\text { Saya dapat memahami lambang atau } \\
\text { simbol yang digunakan pada buku ini }\end{array}$ & $\begin{array}{l}\text { Kurang } \\
\text { Sangat Baik } \\
\text { Baik } \\
\text { Cukup }\end{array}$ & $\begin{array}{l}0 \\
9 \\
14 \\
5 \\
0\end{array}$ & $78.57 \%$ & Baik \\
\hline 19 & $\begin{array}{l}\text { Saya dapat memahami istilah-istilah } \\
\text { dalam buku ini. }\end{array}$ & $\begin{array}{l}\text { Kurang } \\
\text { Sangat Baik } \\
\text { Baik } \\
\text { Cukup }\end{array}$ & $\begin{array}{c}0 \\
4 \\
20 \\
4\end{array}$ & $75.00 \%$ & Baik \\
\hline 20 & $\begin{array}{l}\text { Materi dalam buku ini mendorong } \\
\text { keingintahuan saya }\end{array}$ & $\begin{array}{l}\text { Kurang } \\
\text { Sangat Baik } \\
\text { Baik } \\
\text { Cukup }\end{array}$ & $\begin{array}{l}0 \\
10 \\
16 \\
2\end{array}$ & $84.82 \%$ & Baik \\
\hline 21 & $\begin{array}{l}\text { Penyajian materi dalam buku ini } \\
\text { mendorong saya untuk berdiskusi dengan } \\
\text { teman-teman }\end{array}$ & $\begin{array}{l}\text { Kurang } \\
\text { Sangat Baik } \\
\text { Baik } \\
\text { Cukup }\end{array}$ & $\begin{array}{c}0 \\
6 \\
16 \\
6\end{array}$ & $75.00 \%$ & Baik \\
\hline 22 & $\begin{array}{l}\text { Buku ini memuat latihan soal yang dapat } \\
\text { menguji seberapa jauh pemahaman saya } \\
\text { mengenai materi yang telah dibahas }\end{array}$ & $\begin{array}{l}\text { Kurang } \\
\text { Sangat Baik } \\
\text { Baik } \\
\text { Cukup }\end{array}$ & $\begin{array}{l}0 \\
12 \\
15 \\
1\end{array}$ & $84.82 \%$ & Baik \\
\hline 23 & $\begin{array}{l}\text { Latihan soal yang digunakan dalam buku } \\
\text { ini sesuai dengan materi }\end{array}$ & $\begin{array}{l}\text { Nuirang Baik } \\
\text { Baikat Baik } \\
\text { Cukup }\end{array}$ & $\begin{array}{l}0 \\
18 \\
1\end{array}$ & $82.14 \%$ & Baik \\
\hline 24 & $\begin{array}{l}\text { Saya dapat memahami materi dalam buku } \\
\text { ini dengan mudah }\end{array}$ & $\begin{array}{l}\text { Kurang } \\
\text { Sangat Baik } \\
\text { Baik } \\
\text { Cukup } \\
\text { Kurang }\end{array}$ & $\begin{array}{c}\circ \\
9 \\
13 \\
6 \\
0 \\
0\end{array}$ & $77,68 \%$ & Baik \\
\hline 25 & $\begin{array}{l}\text { Saya merasa lebih mudah belajar dengan } \\
\text { menggunakan buku ini }\end{array}$ & $\begin{array}{l}\text { Suingat Baik } \\
\text { Baika Baik } \\
\text { Cukup }\end{array}$ & $\begin{array}{l}0 \\
8 \\
14 \\
6 \\
0\end{array}$ & $76,79 \%$ & Baik \\
\hline 26 & $\begin{array}{l}\text { Saya sangat tertarik menggunakan buku } \\
\text { ini }\end{array}$ & $\begin{array}{l}\text { Sangat Baik } \\
\text { Baik } \\
\text { Cukup } \\
\text { Kurang }\end{array}$ & $\begin{array}{l}10 \\
17 \\
1 \\
0\end{array}$ & $83,04 \%$ & Baik \\
\hline 27 & $\begin{array}{l}\text { Buku ini membuat saya senang } \\
\text { mempelajari mata pelajaran pekerjaan } \\
\text { dasar elektromekanik }\end{array}$ & $\begin{array}{l}\text { Sangat Baik } \\
\text { Baik Baik } \\
\text { Cukup }\end{array}$ & $\begin{array}{l}13 \\
13 \\
2 \\
0\end{array}$ & $84,82 \%$ & Baik \\
\hline 28 & $\begin{array}{l}\text { Dengan menggunakan buku ini saya } \\
\text { belajar menjadi lebih terarah dan runtut }\end{array}$ & $\begin{array}{l}\text { Kurang } \\
\text { Sangat Baik } \\
\text { Baik } \\
\text { Cukup } \\
\text { Kurang }\end{array}$ & $\begin{array}{l}0 \\
8 \\
17 \\
3 \\
0\end{array}$ & $79,46 \%$ & Baik \\
\hline 29 & $\begin{array}{l}\text { Buku ini memiliki kesesuaian gambar } \\
\text { untuk memperjelas materi }\end{array}$ & $\begin{array}{l}\text { Kuinang Setuju } \\
\text { Sangat Setuju } \\
\text { Baikat Baik } \\
\text { Baik }\end{array}$ & $\begin{array}{l}10 \\
16 \\
2 \\
2\end{array}$ & $82,14 \%$ & Baik \\
\hline 30 & 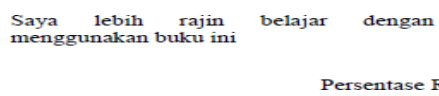 & $\begin{array}{l}\text { Cukup } \\
\text { Sangat Baik } \\
\text { Baik } \\
\text { Cukup } \\
\text { Kurang } \\
\text { ta-Rata }\end{array}$ & $\begin{array}{c}0 \\
4 \\
24 \\
0 \\
0\end{array}$ & $\begin{array}{l}78,57 \% \\
80.24 \%\end{array}$ & Baik \\
\hline
\end{tabular}


Tabel 6 menyatakan bahwa terdapat 30 poin penilaian yang mencakup aspek kelayakan isi, aspek penyajian materi, dan aspek manfaat yang diujikan terhadap bahan ajar dasar dan pengukuran listrik yang peneliti kembangkan. Pada aspek kelayakan isi, aspek penyajian materi, dan aspek manfaat terhadap buku ajar dasar dan pengukuran listrik termasuk dalam kategori baik. Persentase rata-rata total dari ketiga puluh poin tersebut adalah sebesar $80,24 \%$ yang termasuk dalam kategori baik, yang artinya tidak memerlukan adanya revisi kembali.

Pada tahap uji coba terbatas, penilaian dilakukan oleh tiga orang expert judgement dan 13 orang peserta didik. Setelah melakukan pengujian, hasil uji secara umum dinyatakan baik. Terdapat beberapa bagian pada bab yaitu kedalaman materi dan contoh-contoh latihan, penyajian bahasa yang sederhana dan lugas, tampilan dan tata letak gambar diharapkan lebih proporsional dengan ukuran buku serta sudut pandang gambar harus menarik. Perbaikan yang dilakukan adalah pada awal buku ditulis kompetensi inti dan kompetensi dasar, menambahkan materi pada beberapa bab dan contoh latihan, menggunakan bahasa yang lugas dan penyajian bahasa yang sesuai dengan peserta didik, memperbaiki tampilan gambar agar sesuai dengan ukuran buku, tata letak dan sudut pandang gambar harus menarik. Hasil uji menyatakan bahwa bahan ajar dasar dan pengukuran listrik dinilai baik dan layak digunakan sebagai bahan ajar. Pada tahap uji coba lebih luas, penilaian dilakukan oleh 28 orang peserta didik. Hasil uji coba ini untuk melihat bagaimana grafik peningkatan produk setelah di revisi. Berdasarkan hasil uji coba terbatas dan hasil uji coba lebih luas yang dilaksanakan oleh peserta didik maka grafik persentase hasil penilaian peserta didik terhadap kelayakan buku ajar yang meliputi aspek kelayakan isi, aspek penyajian materi, dan aspek manfaat dapat dilihat pada Gambar 1 .

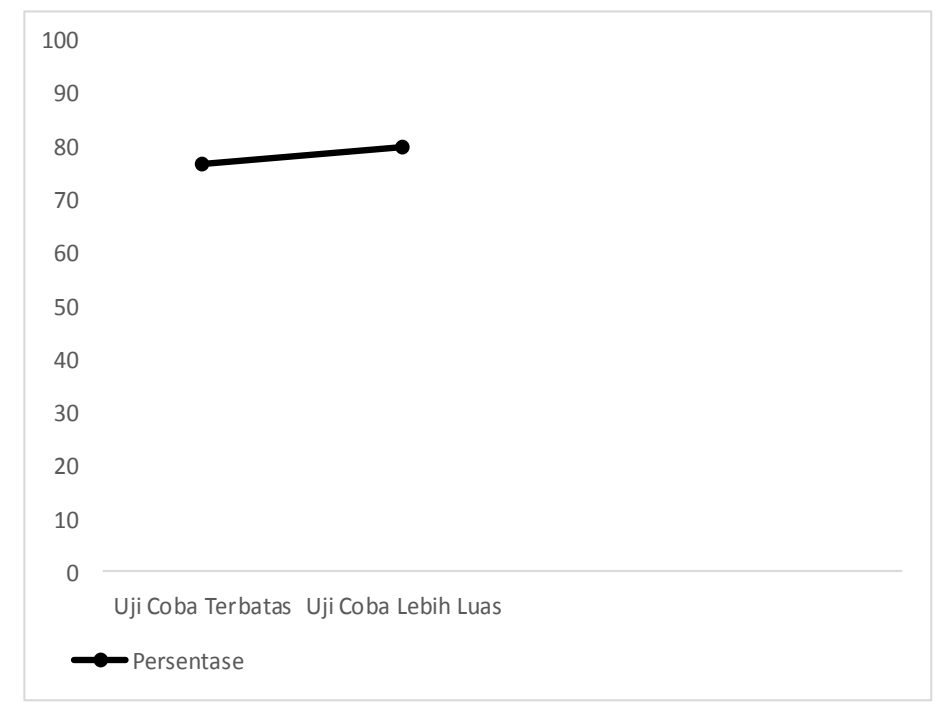

Gambar 1. Grafik Persentase Hasil Uji Kelayakan Peserta Didik

Pada Gambar 1 terlihat persentase ratarata pada uji coba terbatas mencapai $77,05 \%$ dengan kategori baik, kemudian persentase ratarata pada uji coba lebih luas mencapai $80,24 \%$ d engan kategori baik. Maka dapat disimpulkan bahwa pengembangan bahan ajar dasar dan pengukuran listrik ini terdapat peningkatan 3,19\% dari uji coba terbatas ke uji coba lebih luas. 


\section{SIMPULAN}

Hasil analisis data penelitian dan pengembangan buku ajar dasar dan pengukuran listrik, dapat disimpulkan hal-hal sebagai berikut: (1) Pengembangan bahan ajar dasar dan pengukuran listrik yakni bahan dikembangkan dari kurikulum 2013 dan silabus. Materi pelajaran dasar dan pengukuran listik bahannya dikembangkan mulai dari bahan arus listrik dan arus elektron, bahan-bahan listrik, elemen pasif, elemen aktif, rangkaian resistif arus searah, teorema dua kutub, daya dan usaha, peralihan rangkaian, sistem satuan pengukuran, alat ukur dan pengukuran listrik, serta jenis alat ukur. (2) Kelayakan bahan ajar dasar dan pengukuran listrik divalidasi dan dinilai oleh expert judgement dari aspek kelayakan isi, aspek bahasa, aspek kegrafikan, sedangkan untuk keterbacaan dan keterpakaian bahan ajar dasar dan pengukuran listrik di uji cobakan pada sejumlah siswa dengan hasil yang termasuk dalam kategori baik.

\section{DAFTAR RUJUKAN}

Harjanto. 2008. Perencanaan Pengajaran. Jakarta: Rineka Cipta

Prastowo, A. 2012. Panduan Kreatif Membuat Bahan Ajar Inovatif. Jogjakarta: Diva Press

Sugiono. 2012. Metode Penelitian Kuantitatif, Kualitatif dan $R \& D$. Bandung: Alfabeta

Tim Penyusun Direktorat Pembinaan Sekolah Menegah atas Dirjen Manajemen Pendidikan Dasar dan Menengah Atas. 2008. Panduan Pengembangan Bahan Ajar. Jakarta: Depdiknas

Widodo, C. dan Jasmadi. 2008. Buku Panduan Menyusun Bahan Ajar. Jakarta: PT Elex Media Komputindo 